GRASAS Y ACEITES 70 (4)

October-December 2019, e332

ISSN-L: 0017-3495

https://doi.org/10.3989/gya.0929182

\title{
Efficiency of ultrasound assisted extract of Delonix regia petals as natural antioxidant on the oxidative stability of sunflower oil
}

\author{
M.K.S. Morsi, N.F.S. Morsy ${ }^{\bowtie}$ and H.S. Golshany \\ Food Science Dept., Faculty of Agriculture, Cairo University, Egypt \\ ${ }^{\bowtie}$ Corresponding author: nanafsm@yahoo.com
}

Submitted: 08 September 2018; Accepted: 23 January 2019; Published online: 23 July 2019

\begin{abstract}
SUMMARY: The possibility of improving the oxidative stability of sunflower oil by enriching it with carotenoids from Delonix regia petals was studied. A combination of ultrasound-assisted extraction and stirring techniques was used. The optimal conditions were material/solvent ratio of 1:20 (w/v), ultrasonic power of $30 \mathrm{~W}$ and extraction time of $50 \mathrm{~min}$. Under these conditions, the yield of total carotenoids was $503.0 \mu \mathrm{g} / \mathrm{g}$ dry weight. Increasing the acoustic power density degraded carotenoids. A HPLC analysis was used for the quantification of $\beta$-carotene in the extract. The DPPH radical scavenging activity and ferric reducing antioxidant power of the carotenoid-rich extract were found to be superior to the standard Butylated hydroxyl toluene (BHT). The enrichment of sunflower oil with carotenoid-rich extract at $67.46 \mathrm{mg}$ carotenoids $/ \mathrm{kg}$ oil improved its oxidative stability by more than $50 \%$ as measured by the Rancimat method. These results suggest that the investigated extract has the potential to be used as a bio-preservative in food products.
\end{abstract}

KEYWORDS: Carotenoids; Delonix regia; Oxidative stability; Sunflower oil; Ultrasonic

RESUMEN: Eficiencia de la extracción asistida por ultrasonido de pétalos de Delonix regia como antioxidante natural en la estabilidad oxidativa del aceite de girasol. Se estudió la posibilidad de mejorar la estabilidad oxidativa del aceite de girasol enriqueciéndolo con carotenoides de pétalos de Delonix regia. Se utilizaron técnicas combinadas de extracción asistida por ultrasonido y técnicas de agitación. Las condiciones óptimas fueron una relación material/ disolvente de 1:20 (p/v), una potencia ultrasónica de $30 \mathrm{~W}$ y un tiempo de extracción de $50 \mathrm{~min}$. En estas condiciones, el rendimiento de carotenoides totales fue de 503,0 $\mu \mathrm{g} / \mathrm{g}$ de peso seco. El aumento de la densidad de potencia acústica degrada a los carotenoides. El análisis por HPLC se utilizó para la cuantificación de $\beta$-caroteno en el extracto. Se encontró que la actividad de captación de radicales DPPH y el poder antioxidante reductor férrico del extracto rico en carotenoides es superior al del butilhidroxitolueno estándar (BHT). El enriquecimiento de aceite de girasol con extracto rico en carotenoides a 67,46 mg de carotenoides $/ \mathrm{kg}$ de aceite mejoró su estabilidad oxidativa en más del 50\% según lo medido por el método de Rancimat. Estos resultados proponen que el extracto investigado tiene el potencial de ser utilizado como conservante biológico en productos alimenticios.

PALABRAS CLAVE: Aceite de girasol; Carotenoides; Delonix regia; Estabilidad oxidativa; Ultrasonido

ORCID ID: Morsi MKS https://orcid.org/0000-0003-2061-6075, Morsy NFS https://orcid.org/0000-0001-7648-2489, Golshany HS https://orcid.org/0000-0002-1246-5337

Citation/Cómo citar este artículo: Morsi MKS, Morsy NFS, Golshany HS. 2019. Efficiency of ultrasound assisted extract of Delonix regia petals as natural antioxidant on the oxidative stability of sunflower oil. Grasas Aceites 70 (4), e332. https://doi.org/10.3989/gya.0929182

Copyright: (C2019 CSIC. This is an open-access article distributed under the terms of the Creative Commons Attribution 4.0 International (CC BY 4.0) License. 


\section{INTRODUCTION}

Sunflower oil is susceptible to oxidation because it contains high levels of polyunsaturated fatty acids. Lipid oxidation produces rancid flavors and degrades the quality and safety of food products which are rich in oils (Upadhyay and Mishra, 2015). Oxidative stability is an important indicator for evaluating the ability of oils to resist oxidation through processing and storage. Natural and synthetic antioxidants are added to edible oils to delay oxidation, and prolong the shelf-life of food products. The use of natural antioxidants is in increasing demand (Mezza et al., 2018).

Delonix regia (Bojer ex Hook), commonly known as Poinciana regia, Royal Poinciana, or Gul mohar, is a member of the Caesalpinioideae family. It is a large ornamental tree with red peacock flowers (Vargas et al., 2010). The floral petals are sweetish-sour in taste and are often eaten by children and used by natives for confections (Bhatt et al., 2000). The water extract of the flowers is used for medicinal purposes (Adjé et al., 2010). Veigas et al., (2012) reported that the antioxidant potential of $D$. regia flowers may be related to their high content of carotenoids.

Carotenoid pigments are responsible for the color of fruits and flowers, which plays an important role in attracting insects to act as pollinators and seed dispersion vehicles (Hornero-Méndez and Mínguez-Mosquera, 2000). Conventional methods have been used to recover valuable compounds from plant food matrices. Food scientists have reported on processes with a green and sustainable extraction concept.

The ultrasound-assisted extraction (UAE) technique has been developed to improve the extraction rate and extraction yield of bioactive compounds by reducing energy and time compared to conventional methods (Goula et al., 2017). Ultrasound produces cavitation in the extraction media that directs a jet of liquid at the surface, causing cell rupture of the material subjected to extraction (Roselló-Soto et al., 2015). The UAE of polyphenols from D. regia dried flowers using methanol shortened maceration time significantly (Adje et al., 2010). UAE is used to obtain antioxidants and phenolic compounds from plant materials at high yield with low extraction solvent volume and low cost in a short time (Chemat et al., 2018).

The present study is the first to focus on the extraction of carotenoids from Delonix regia petals by ultrasound technique.

The objectives of the present research aim:

1. To evaluate the impact of UAE variables (ultrasonic intensity, sonication time, and solvent/ plant material ratio) on the enhancement of carotenoid extraction; (ii) To characterize the antioxidant activities of the carotenoid-rich extract; and (iii) To explore the effective level of the carotenoid-rich extract and dried petals (by infusion), which could improve the oxidative stability of refined sunflower oil.

\section{MATERIALS AND METHODS}

\subsection{Plant material}

Seven $\mathrm{kg}$ of D. regia (Boj.) Raf. petals were collected from the garden at the Department of Food Science, Faculty of Agriculture, Cairo University during the bloom season (May-June 2016). The freshly harvested petals $(80.38 \%$ moisture $)$ were shade dried at room temperature till their moisture content reached $8.28 \%$. For pigment extraction and analysis, the petals were ground into a fine powder and placed in brown glass bottles in a dark well-ventilated place till extraction.

\subsection{Chemicals and reagents}

2,2-diphenyl-1-picrylhydrazyl (DPPH), butylated hydroxyl toluene (BHT), ferric chloride, trichloroacetic acid, phosphate buffer $\mathrm{pH}$ 6.6, potassium ferricyanide and standards of $\beta$-carotene, lutein and lycopene were purchased from Sigma-Aldrich Fine Chemicals (St. Louis, MO). All solvents used (acetonitrile, hexane and methanol) were of HPLC grade and were obtained from Merck (Darmstadt, Germany). Refined, bleached and deodorized sunflower oil with no added antioxidants was procured from Cairo Oil and Soap Company, Egypt.

\subsection{Carotenoid extraction using different techniques}

\subsubsection{Ultrasonic extraction (US) and stirring $(S)$}

UAE was performed using a Fisher Sonic Dismemberator, Model 300, $50 \mathrm{~Hz}$, USA. Ten grams of the dried powder were used for each extraction process. Each extraction process was repeated three times. The ultrasound extraction was carried out using dried powder to solvent (a nonpolar solvent, hexane) ratios of 1:20 and 1:30 (w/v). The mixture was subjected to ultrasonic radiation using an ultrasound generator, equipped with an ultrasonic horn probe with a $19 \mathrm{~mm}$ diameter tip immersed $5 \mathrm{~mm}$ into the solution, in the center of the vessel. The ultrasonic intensity levels were designed as $10 \%$ of the maximal output power $(30 \mathrm{~W}), 20 \%$ of the maximal output power $(60 \mathrm{~W})$ and $30 \%$ of the maximal output power $(90 \mathrm{~W})$, at room temperature $\left(25^{\circ} \mathrm{C}\right)$. The highest temperature of the system reached $28{ }^{\circ} \mathrm{C}$. The acoustic energy density (W) was calculated according to Upadhyay et al., (2015) by dividing the dissipated power by the volume of solvent (L) used during extraction. Sonication was performed at three different levels of acoustic energy density 
$(0.73,1.46$ and $2.44 \mathrm{~W} / \mathrm{L})$. The experimental process was protected from light for less attenuation of the carotenoids during extraction by covering with aluminum foil. During the ultrasound extraction (US), the samples were continuously stirred (S) by a magnetic stirrer (Model MS-300, China). After standing and layering the extraction media, the extracts were collected and filtered to separate the plant material from the liquid extract. Aliquots of the extract were withdrawn at 10,30, 50, 80,100 and $120 \mathrm{~min}$.

As a control, the conventional solvent extraction technique was performed by magnetic stirring $(\mathrm{S})$, at room temperature $\left(25^{\circ} \mathrm{C}\right)$ using the same material/ solvent ratios and extraction times to evaluate the efficiency of ultrasound.

\subsection{Preparation of sunflower oil enriched with carotenoids at different levels}

\subsubsection{Addition of dried extract rich in carotenoids}

The extract with the highest level of carotenoids was evaporated under vacuum using a rotary evaporator (Model N-1000 Tokyo Rikakikai Co., LTD., Japan) at $40{ }^{\circ} \mathrm{C}$. The dried extract $(0.05-0.125 \mathrm{~g})$ with its known content of total carotenoids was used for enriching sunflower oil samples (10 mL each) with carotenoids at 67.46 and $159.56 \mathrm{mg}$ carotenoids/Kg oil.

\subsubsection{Infusion of $\mathrm{D}$. regia flower powder into sunflower oil by maceration}

D. regia dried flower powder-oil mixtures were prepared according to the method of Ammar et al., (2017), at $10 \%$ and $20 \%(\mathrm{w} / \mathrm{v})$ using $1 \mathrm{~L}$ of sunflower oil for each sample. The mixtures were kept in dark glass bottles for 20 days at $5{ }^{\circ} \mathrm{C}$. The mixtures were subjected to constant agitation for $2 \mathrm{~h}$ at room temperature, daily. After the maceration step, the plant material was removed by filtration and the total carotenoids in each extract was determined. Each experiment was carried out three times.

\subsection{Visible scanning}

VIS spectra were performed using a Jasco V-550 UV/VIS multi-wavelength Spectrophotometer (Jasco Applied Sciences Ltd., Droxford, United Kingdom) from $405-505 \mathrm{~nm}(2 \mathrm{~nm} / \mathrm{s})$ of the extracts. Scanning of these extracts was followed after $10 \mathrm{~min}$ of extraction till the rate of extraction yield was limited (the increment of carotenoids/min was less than $10 \mu \mathrm{g}$ ).

\subsection{Quantification of total carotenoids}

The concentration of total carotenoids in each extract was determined by measuring its absorbance in hexane at $448 \mathrm{~nm}$ using the $\beta$-carotene absorption coefficient $\left(\mathrm{A}^{1 \%}{ }_{1 \mathrm{~cm}}=2592\right)$ according to Rodriguez-Amaya
(2001) using UV-visible spectrophotometer (Unico UV-2000, USA). Hexane was used as a blank. The carotenoid extraction yield was expressed as $\mu \mathrm{g}$ of carotenoids/g of dry weight (dw) sample.

The carotenoid content of pigmented sunflower oil was determined according to Goula et al., (2017) with some modifications as follows: three grams of sample (infused or enriched with carotenoid-rich extract) were accurately weighed and dissolved in hexane up to a final volume of $10 \mathrm{~mL}$. The carotenoid content was measured as $\beta$-carotene and was calculated from the absorbance of the pigmented oil solution against sunflower oil as a blank.

\subsection{HPLC analysis of $\beta$-carotene}

The highest carotenoid extract was filtered through a $0.45 \mu \mathrm{m}$ membrane filter. Before injection, $50 \mathrm{~mL}$ of the hexane extract was concentrated using a rotary evaporator at $40{ }^{\circ} \mathrm{C}$ under vacuum and redissolved in $10 \mathrm{~mL}$ of hexane. Twenty $\mu \mathrm{L}$ of the extract were injected for HPLC analysis. HPLC separation was performed using a HPLC system (Agilent Technologies 1100 series, USA) equipped with a solvent degasser, quaternary pump, auto sampler, and UV/VIS diode array detector. A LiChrospher 5 RP Select B $5 \mu \mathrm{m}$ particle size $(250 \times 4.0 \mathrm{~mm})$ HPLC column was used. Acetonitrile - methanol (70:30 $(\mathrm{v} / \mathrm{v})$ was used as the mobile phase. The detection wavelength was set at $448 \mathrm{~nm}$ with a flow rate at $1 \mathrm{~mL} / \mathrm{min}$. Ten $\mu \mathrm{L}$ of the standard mixture $(25 \mu \mathrm{g}$ lutein, $22.5 \mu \mathrm{g}$ lycopene and $100 \mu \mathrm{g} \beta$-carotene $/ \mathrm{mL}$ ) were injected and submitted to the same HPLC conditions as the extract analysis.

\subsection{Evaluation of the antioxidant activities of the carotenoid-rich extract}

\subsubsection{DPPH free radical scavenging activity}

The radical scavenging activity of the carotenoidrich extract towards DPPH radicals was determined according to Gulluce et al., (2007). The dried extract was dissolved in $5 \mathrm{~mL}$ hexane using a volumetric flask. The initial absorbance of the DPPH solution $(40 \mu \mathrm{g} / \mathrm{mL})$ was 1.221 . BHT solutions in concentrations of $0,25,50$ and $100,200 \mu \mathrm{g} / \mathrm{mL}$ were used as reference. The concentration of the extract that was required for inhibiting $50 \%$ of the DPPH radicals was determined and expressed as the $\mathrm{IC}_{50}$ value.

\subsubsection{Ferric reducing antioxidant power (FRAP)}

The reducing power of the dried extract dissolved in hexane was determined at $700 \mathrm{~nm}$ according to the method of Oyaizu (1986). BHT solutions in concentrations of $0,3.12,6.25,12.5,25 \mu \mathrm{g} / \mathrm{mL}$ were used as standard reference. $\mathrm{IC}_{50}$ (Concentration of the extract providing absorbance 0.5 ) was calculated 
from the graph using extract concentration versus absorbance.

\subsection{Analyses of sunflower oil}

The acid value and peroxide value of the refined sunflower oil were determined according to AOCS (1998).

\subsection{Oxidative stability of sunflower oil enriched with carotenoids from flower powder or its extract using Rancimat method at $110{ }^{\circ} \mathrm{C}$}

The oxidative stability was assessed by measuring the induction time (h), in a Rancimat apparatus (Metrohm AG Series 679, Herison, Switzerland) according to the AOCS Official Method Cd 12b-92 (AOCS, 1998). Each sample of sunflower oil (3 g) was heated to $110 \pm 2{ }^{\circ} \mathrm{C}$ and subjected to airflow at $20 \mathrm{~L} / \mathrm{h}$. The collected polar volatile compounds in water increased its conductivity $(\mu \mathrm{S} / \mathrm{cm})$. Conductivity was measured throughout the analysis. Oxidative stability was compared with that of sunflower oil supplemented with $200 \mathrm{ppm}$ BHT. The induction time was determined from the inflection point of the conductivity curve. The relative stability was calculated according to the following formula:

Relative stability = Induction time of the sample oil/Induction time of the control.

\subsection{Statistical analysis}

All the experiments were carried out in triplicate and the results were expressed as the mean value \pm SD. Data were analyzed using one-way analysis of variance (ANOVA). Duncan's multiple range test was used to compare the significance of differences at $\mathrm{P}<0.05$.

\section{RESULTS AND DISCUSSION}

\subsection{Visible scanning}

The visible spectra of the hexane extracts from $10 \mathrm{~min}$ to $50 \mathrm{~min}$ extraction time were recorded from $405 \mathrm{~nm}$ to $505 \mathrm{~nm}$. The rate of the extracted carotenoids decreased to $<10 \mu \mathrm{g}$ carotenoids/min after $50 \mathrm{~min}$. The obtained visible spectra are shown in Figure 1.

The spectra illustrated three characteristic absorption peaks at $448 \mathrm{~nm}$ and $470 \mathrm{~nm}$ and a shoulder at $427 \mathrm{~nm}$ with the maximum absorption at $448 \mathrm{~nm}$. These spectra are in agreement with those found by Sricharoen et al., (2016) for $\beta$-carotene. The extracts obtained by magnetic stirring only or at low material solvent ratio or at a short extraction time or at high ultrasonic intensity showed low levels of absorption indicating low carotenoid concentration. The extract that was obtained with the highest level of carotenoids in a nearly short time (50 min) was selected for further analysis.

\subsection{HPLC analysis}

The selected extract with the highest level of carotenoids was analyzed by HPLC for the confirmation and quantification of $\beta$-carotene in this extract (1:20 plant material/solvent ratio, $10 \%$ ultrasonic intensity for $50 \mathrm{~min}$ ) (Figure 2). The concentration of $\beta$-carotene was found to be $31.86 \mu \mathrm{g} / \mathrm{mL}$.

\subsection{Effect of extraction time}

The optimization of the extraction time is of great importance to minimize energy costs. The ultrasonic with stirring technique (US+S) was significantly more efficient for the extraction of carotenoids than stirring (S) alone at each extraction time, regardless of material/solvent ratio as shown in Figure 3. The ultrasound efficiency could be due to its capability to penetrate and rupture the cell walls and improve the mass transfer of soluble constituents from solid material to solvent phase (Wang and Weller, 2006). Extending extraction time from 10 to $120 \mathrm{~min}$ with or without ultrasonic caused a significant increase in the extracted carotenoids, regardless of the material/solvent ratio used.

The highest yield of total carotenoids was obtained with a material/solvent ratio of $1: 20$ at $10 \%$ ultrasonic intensity for $120 \mathrm{~min}$. The yield of extracted carotenoids using material/solvent ratio of 1:20 at $20 \%$ ultrasonic intensity for 100 min was significantly higher than that obtained at the same intensity for a longer time $(120 \mathrm{~min})$. Since the rate of extracting carotenoids decreased to $<10 \mu \mathrm{g}$ carotenoids/min only when extraction time was extended from $50 \mathrm{~min}$ to $120 \mathrm{~min}$, this time was selected as the optimal time for the maximum extraction of carotenoids from petals. In other words, extending the extraction time from $50 \mathrm{~min}$ to $120 \mathrm{~min}$ enhanced the extraction of carotenoids by less than $6 \%$, regardless of the extraction conditions used. This result is in agreement with that found by Ye et al., (2011).

\subsection{Effect of ultrasonic intensity (\%)}

Increasing ultrasonic intensity by higher than $10 \%$ of the maximum output power (energy density $0.73 \mathrm{~W} / \mathrm{L}$ ) was accompanied by a significant decrease in the extracted carotenoids regardless of the material/solvent ratio (Figure 4). Although this low intensity required a longer extraction time, its effect on the product stability is less pronounced than high ultrasonic intensity as reported by Tiwari et al., (2010). At the same time, the extraction performed using 1:20 ratio, ultrasonic intensity 20\% (energy density $1.46 \mathrm{~W} / \mathrm{L}$ ) or higher for $120 \mathrm{~min}$ did not significantly increase the total carotenoid yield that was 

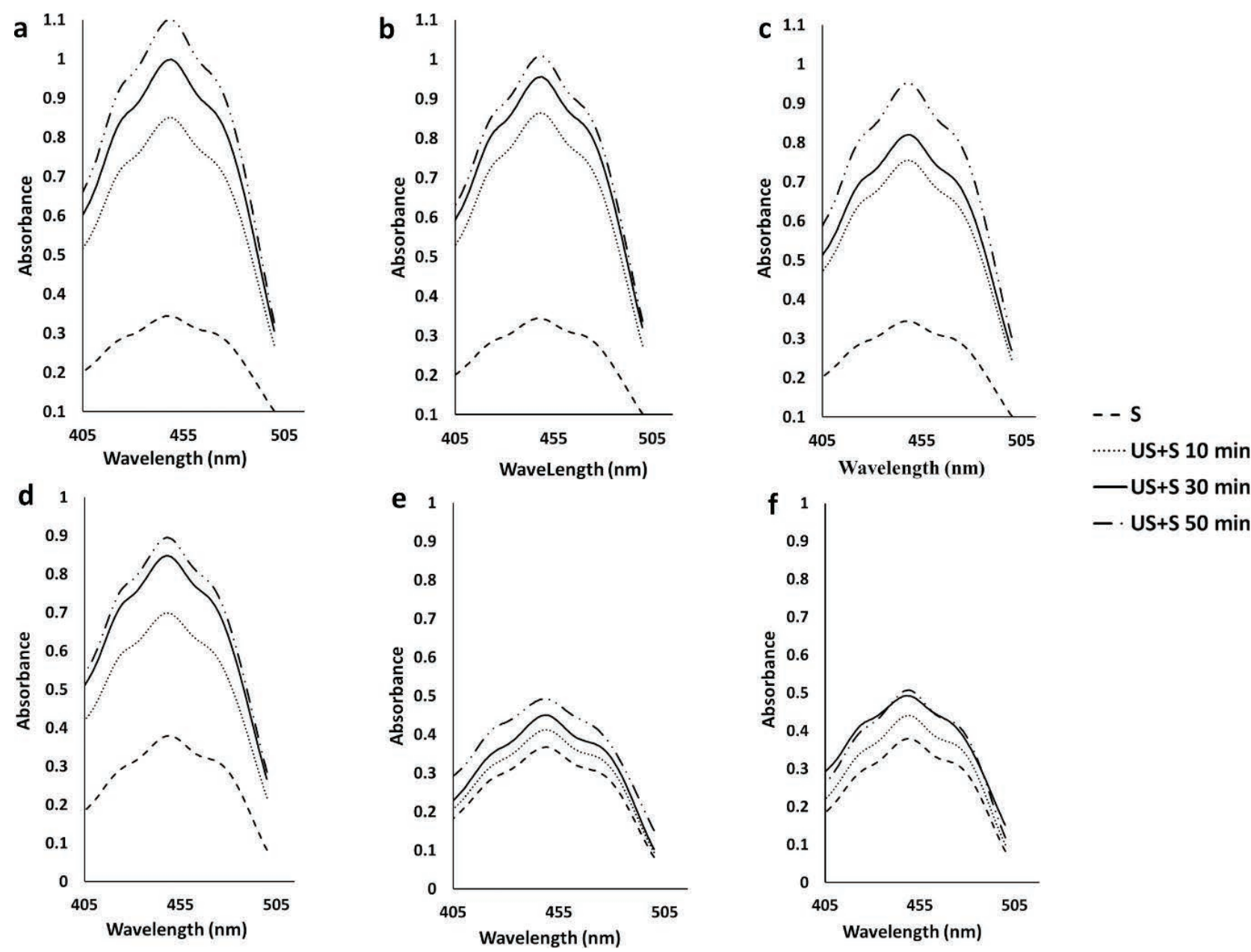

FIGURE 1. Visible spectra of the carotenoid extracts obtained with plant material/solvent ratio 1:20 (a, b, c) and 1:30 (d, e, f) at each investigated ultrasonic intensity $(10 \%, 20 \%, 30 \%$ of the maximal output power), respectively, using magnetic stirring (S) or combination of ultrasonic and magnetic stirring (US). The values refer to a single determination for each treatment.

obtained with conventional stirring only for the same duration. Increasing ultrasonic intensity from $20 \%$ (energy density $1.46 \mathrm{~W} / \mathrm{L}$ ) to $30 \%$ (energy density $2.44 \mathrm{~W} / \mathrm{L}$ ) using a material/solvent ratio of 1:30 for 80 min caused a significant increase in the extracted carotenoids, while after 120 min extraction it did not significantly affect the total carotenoid yield.

Raso et al., (1999) reported that higher acoustic intensity caused a scattering of ultrasonic waves and a reduction in the extraction yield. High ultrasound intensity causes the formation of radicals, which degrades carotenoids (Saini and Keum, 2018). Therefore, low ultrasonic intensity $(10 \%$ of the maximum output power, energy density $0.73 \mathrm{~W} / \mathrm{L}$ ) was selected to eliminate any destruction of the carotenoids present.

\subsection{Effect of material/solvent ratio}

Decreasing material/solvent ratio from 1:20 to 1:30 was accompanied by a remarkable decrease in the extracted carotenoids throughout the extraction process, regardless of the ultrasonic intensity used. This result could be due to the fact that the increment in solvent/material ratio was not high enough to enhance the mass transfer of carotenoids from the plant material. This result is in agreement with that reported by Sachindra and Mahendrakar (2005). Decreasing the material/solvent ratio negatively affects the ultrasonic energy/unit volume of the solvent and the yield of the extractable material (Raza et al., 2017).

\subsection{Antioxidant activities of the flower extract}

\subsubsection{DPPH radical scavenging activity}

This method is based on the ability of the DPPH radical to react with hydrogen donor species. The carotenoid-rich extract indicates its antioxidant activity against $\mathrm{DPPH}$ radicals. $\mathrm{The} \mathrm{IC}_{50}$ of the hexane extract $(3.73 \mu \mathrm{g}$ carotenoids $/ \mathrm{mL})$ was $\sim 10$ times that of the BHT $\left(\mathrm{IC}_{50}=34.7 \mu \mathrm{g} / \mathrm{mL}\right)$ as illustrated in 
a

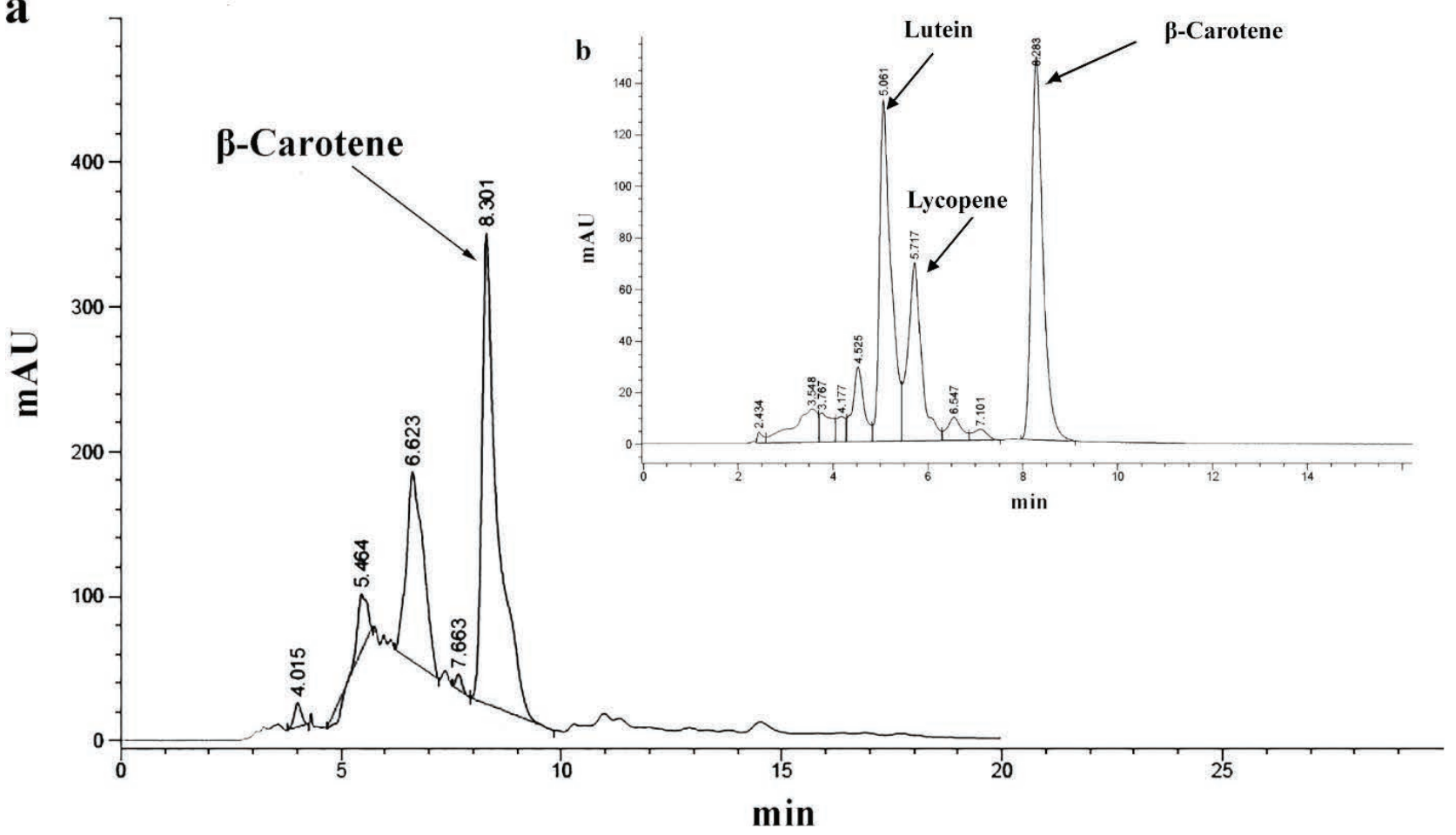

FIGURE 2. HPLC chromatograms of the carotenoid-rich extract (a), and the standard mixture of $\beta$-carotene, lycopene and lutein (b). The values refer to a single determination.

Figure 5 a-b. On the other hand, Shabir et al., (2011) studied the antioxidant activity of different solvent (methanol, ethanol, acetone, and water) extracts of Delonix regia Raf. flowers and the highest DPPH scavenging activity was recorded for the $80 \%$ methanol extract $\left(\mathrm{IC}_{50}\right.$ value $\left.14.8 \mu \mathrm{g} / \mathrm{mL}\right)$.

\subsubsection{Ferric reducing power activity}

The reducing power assay indicates the high antioxidant activity of the investigated carotenoid-rich extract. The $\mathrm{IC}_{50}$ of the extract $(1.36 \mu \mathrm{g}$ carotenoids/ $\mathrm{mL})$ represented $\sim 3$ times that of BHT $\left(\mathrm{IC}_{50}=\right.$ $3.37 \mu \mathrm{g} / \mathrm{mL}$ ) as shown in Figure $5 \mathrm{c}-\mathrm{d}$. Shabir et al., (2011) showed that the $80 \%$ methanol extract from Delonix regia flowers had a low reducing power value $\left(\mathrm{IC}_{50} \sim 4 \mathrm{mg} / \mathrm{mL}\right)$.

\subsection{Oxidative stability of sunflower oil}

Many physical and chemical methods are used to assess the degree of oil deterioration (oxidation). The acid value $(0.38 \mathrm{mg} \mathrm{KOH} / \mathrm{g}$ oil), and peroxide value $\left(0.66 \mathrm{meq} \mathrm{O}_{2} / \mathrm{Kg}\right.$ oil $)$ of the investigated refined sunflower oil (with no added antioxidants) indicate its freshness and its high quality according to the Codex Alimentarius Standards (Codex Alimentarius, 2015). Rancimat test as an accelerated technique is used for measuring the oxidative stability of oils and fats at an elevated temperature and high flow rate of air. The induction time indicates the resistance of oils to oxidative deterioration. The oxidative stability of the sunflower oil samples as affected by different levels of carotenoid-rich extract or infused flower powder is illustrated in Table 1.

The oxidative stability (induction time) of the sunflower oil sample without added extract (control) was $8.65 \mathrm{~h}$. The oxidative stability of sunflower oil increased by $50 \%$ (relative stability $\sim 1.5$ ) when it was enriched with $67.46 \mathrm{mg}$ carotenoids $/ \mathrm{kg}$ oil (using carotenoid-rich extract) or with $155.72 \mathrm{mg}$ carotenoids $/ \mathrm{kg}$ oil (by infusion of oil with $20 \%$ flower powder for 20 days at $5{ }^{\circ} \mathrm{C}$ ).

On the other hand, sunflower oil supplemented with BHT at $200 \mathrm{ppm}$ had a relative stability of 1.26 . This indicates the highest antioxidant efficiency of the carotenoid-rich extract compared to BHT.

This plant extract effectively stabilized sunflower oil against rancidity and the results could be compared with the findings of Upadhyay and Mishra (2015), who increased the oxidative stability of sunflower oil (by about $36 \%$ ) by blending with sage (Salvia officinalis) oleoresin at $200 \mathrm{ppm}$. Upadhyay et al., (2017) delayed the thermo-degradation of sunflower oil during frying $(18 \mathrm{~h})$ by the synergistic combination of oleoresin rosemary, as a natural antioxidant, and ascorbyl palmitate. Induction period values of the oil blend decreased significantly at the end of frying by 1.5 times reduction instead of 5 times reduction in the control sample. Meanwhile, 

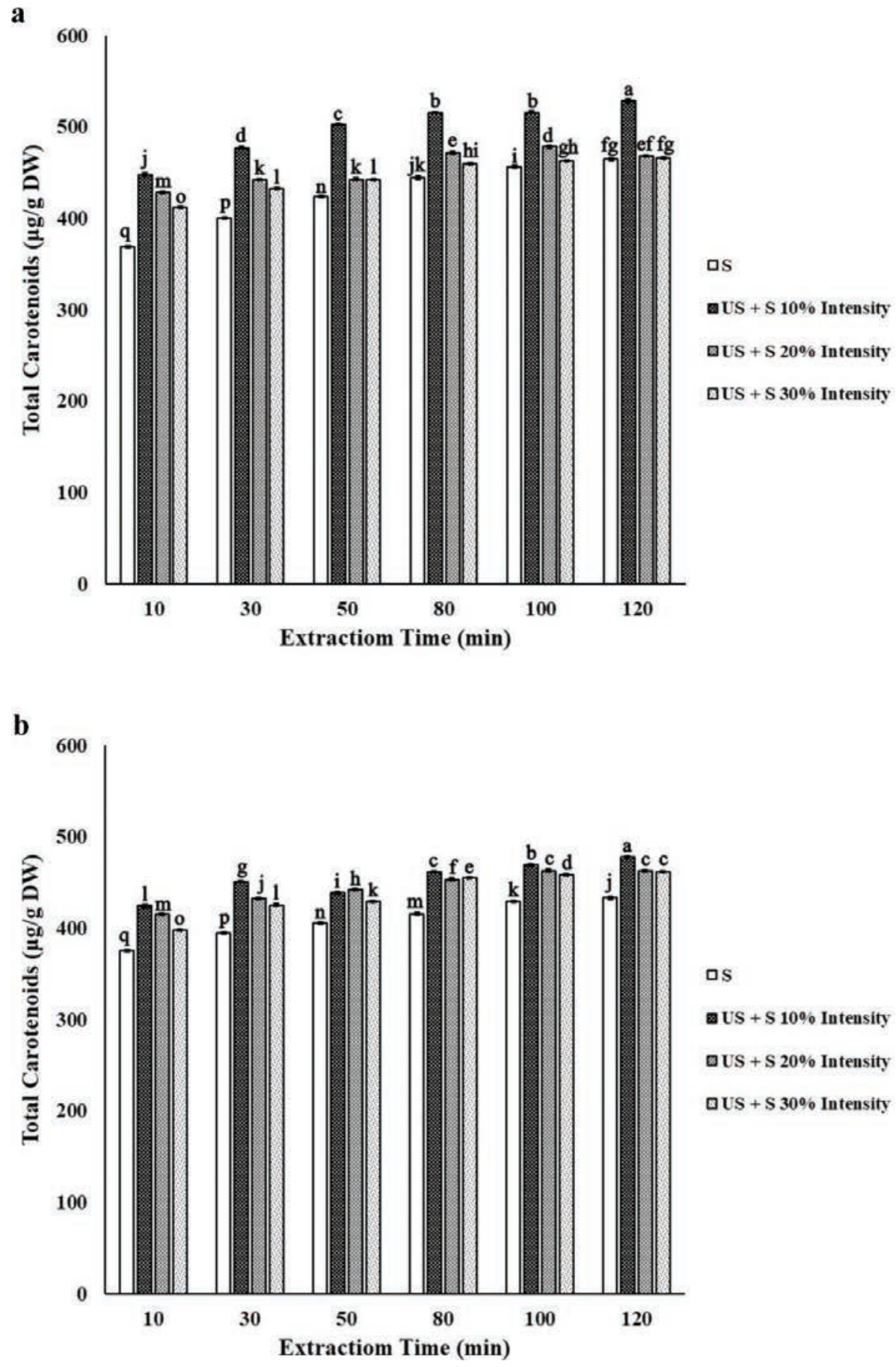

FIGURE 3. Total carotenoid yield obtained after different extraction times using magnetic stirring (S) or combination of ultrasonic and magnetic stirring (US+S) with plant material/solvent ratio 1:20 (a) and 1:30 (b) at each ultrasonic intensity $(10 \%, 20 \%$ and $30 \%)$. The experiment was carried out in triplicate; $n=3$. Values are given as mean \pm SD. Data were analyzed using one-way analysis of variance (ANOVA) and the Duncan test. Different letters on bars indicate significant difference $(\mathrm{P}<0.05)$

the UAE of ground dried tomato waste (containing the skin and seeds of ripe tomato) into refined sunflower oil at $5 \%(\mathrm{w} / \mathrm{v})$ for $50 \mathrm{~min}$ at $20{ }^{\circ} \mathrm{C}$ increased its induction time by $19 \%$ (Nour et al., 2018).

The infusion of flower petals into the investigated oil caused the migration of pigments from petals to oil. Saini and Keum (2018) reported that vegetable oil enriched with carotenoids could be used as a pigmented oil in food formulations. Sachindra and Mahendrakar (2010) extracted carotenoids from shrimp waste using sunflower oil. They reported that the addition of carotenoid 

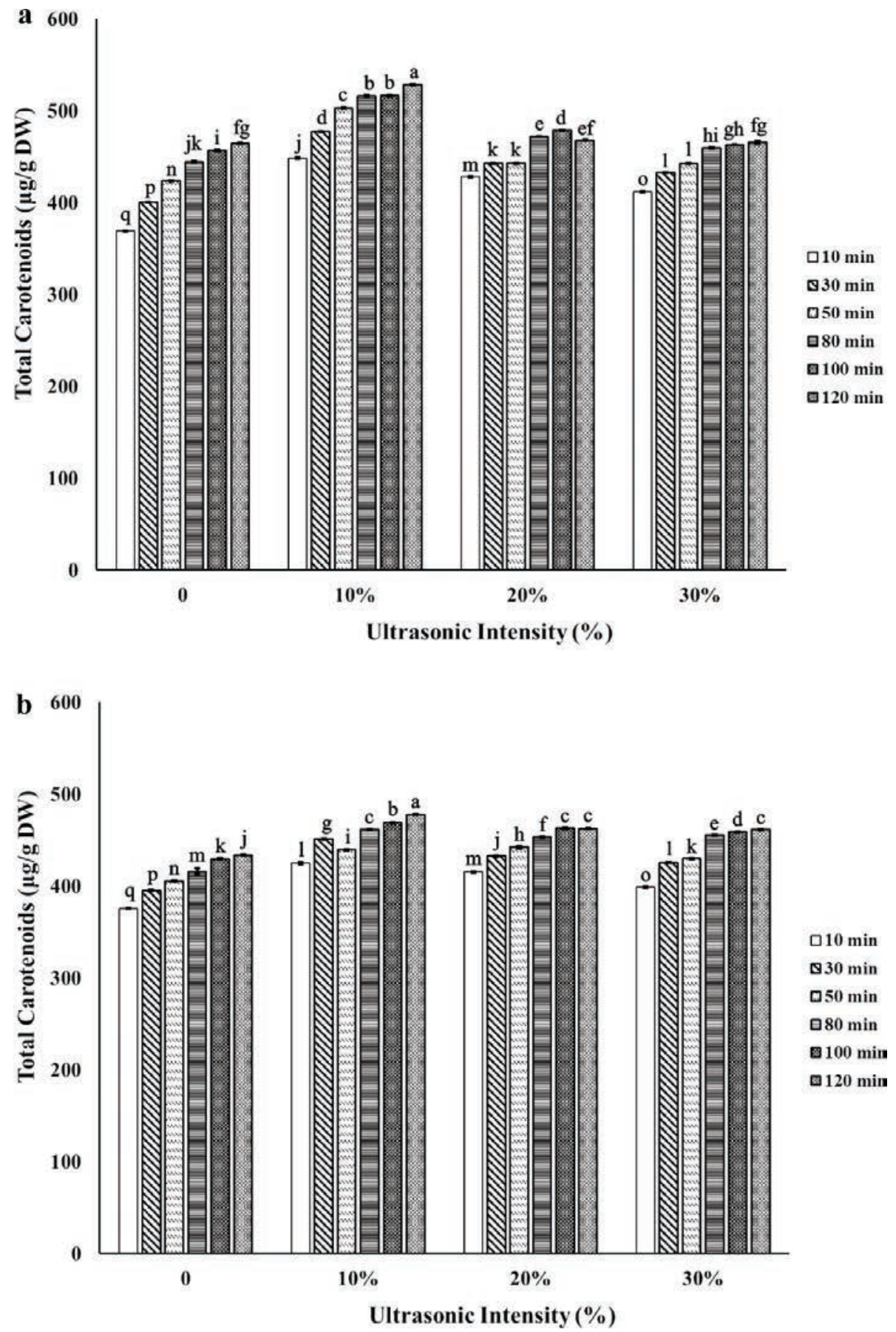

FIGURE 4. Total carotenoid yield obtained by different ultrasonic intensity $(10 \%, 20 \%$ and $30 \%)$ using magnetic stirring (S) or combination of ultrasonic and magnetic stirring (US+S) with plant material/solvent ratio 1:20 (a) and 1:30 (b) at each extraction time $(10,30,50,80,100$ and $120 \mathrm{~min})$. The experiment was carried out in triplicate; $n=3$. Values are given as mean $\pm S D$. Data were analyzed using one-way analysis of variance (ANOVA) and the Duncan test. Different letters on bars indicate significant difference $(\mathrm{P}<0.05)$.

carriers to fish sausage enhanced the color and flavor of the product.

The addition of a higher level of carotenoidrich extract to oil ( $159.56 \mathrm{mg}$ carotenoids/Kg oil) lowered the oxidative stability of the oil by $11 \%$ (relative stability $=0.89$ ), indicating the pro-oxidant activity of this level as reported by Polyakov et al., (2001) and Nour et al., (2018), who found that carotenoids act as a pro-oxidant at a high concentration. 

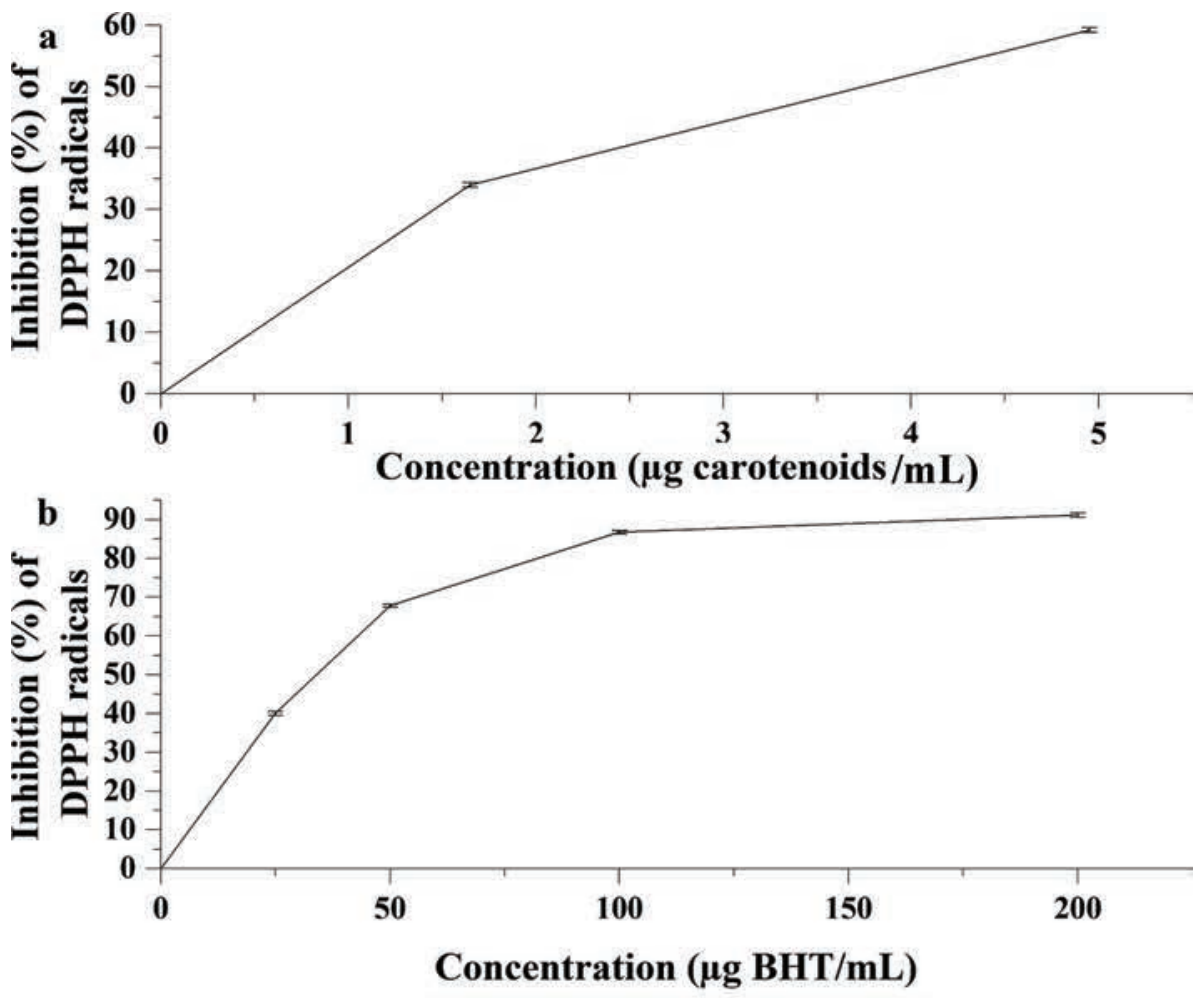

c

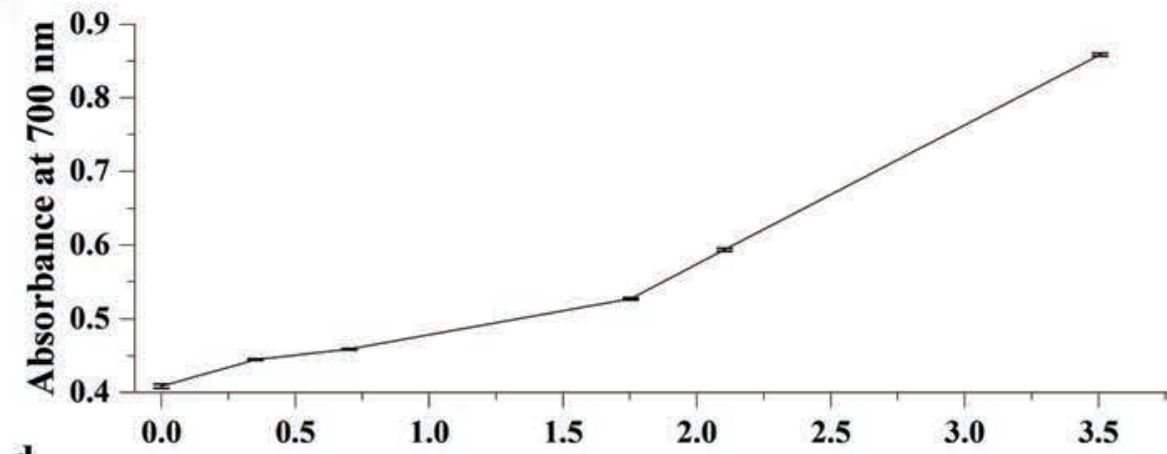

d

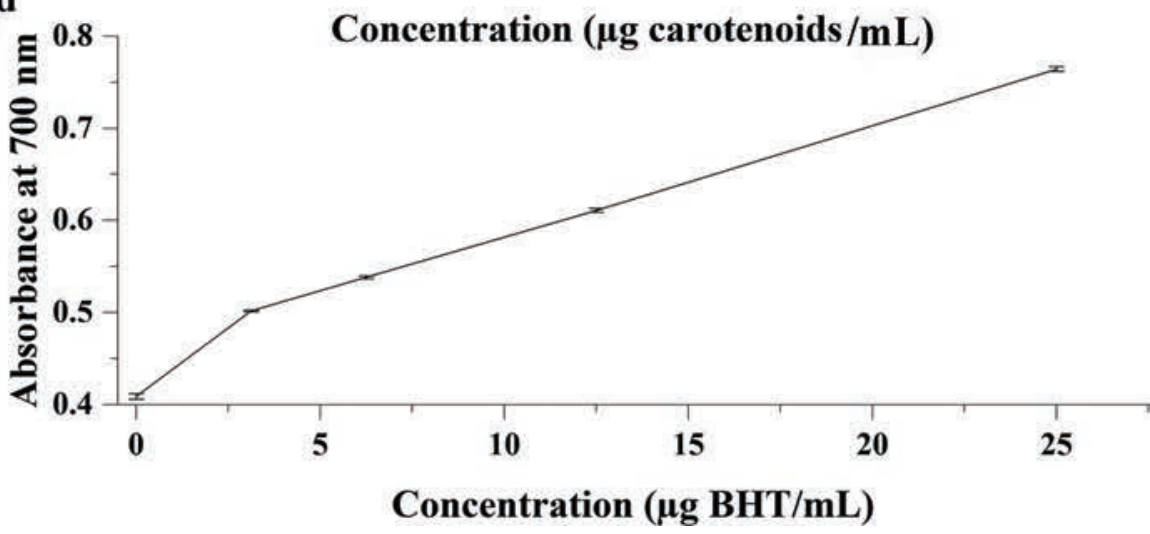

FIGURE 5. Antioxidant activity of the carotenoid-rich extract of D. regia flower powder (a) and BHT as reference standard (b) against DPPH radicals. The ferric reducing power capacity of the carotenoid-rich extract of D. regia flower powder (c) and BHT as reference standard (d). Data are expressed as mean $\pm S D$ of triplicate measurements; $n=3$. Data were analyzed using one-way analysis of variance (ANOVA). 
TABLE 1. Oxidative stability of sunflower oil enriched with different levels of carotenoids using the Rancimat method

\begin{tabular}{lcc}
\hline Sample of Sunflower oil & $\begin{array}{c}\text { Induction } \\
\text { time (h) }\end{array}$ & $\begin{array}{c}\text { Relative } \\
\text { Stability }\end{array}$ \\
\hline Control & $8.65 \pm 0.1$ & 1 \\
$\begin{array}{l}\text { Enriched with } 67.46 \mathrm{mg} \\
\text { carotenoids/Kg oil }\end{array}$ & $13.21 \pm 0.06$ & 1.53 \\
$\begin{array}{l}\text { Enriched with } 159.56 \mathrm{mg} \\
\text { carotenoids/Kg oil }\end{array}$ & $7.76 \pm 0.08$ & 0.89 \\
$\begin{array}{l}\text { Enriched with } 10 \% \text { flower powder } \\
(92.57 \mathrm{mg} \text { carotenoids/Kg oil) }\end{array}$ & $11.29 \pm 0.06$ & 1.30 \\
$\begin{array}{l}\text { Enriched with } 20 \% \text { flower powder } \\
(155.72 \mathrm{mg} \text { carotenoids/Kg oil) }\end{array}$ & $12.69 \pm 0.14$ & 1.47 \\
BHT (200 mg/Kg oil) & $10.9 \pm 0.05$ & 1.26 \\
\hline
\end{tabular}

Data are expressed as mean \pm SD of triplicate determinations $(\mathrm{n}=3)$. Data were analyzed using one-way analysis of variance (ANOVA)

\section{CONCLUSIONS}

The results of this study indicate that the independent factors in the ultrasound extraction had a significant effect on the extraction yield of carotenoids from the petals of Delonix regia. The combination of ultrasound and magnetic stirring (US+S) significantly increased the extraction yield compared to conventional stirring (S). The relatively high material/solvent ratio and low intensity of ultrasonic were efficient for maximum extraction yield. DPPH, FRAP assays and the oxidative stability of sunflower oil measured by the Rancimat reflects the high efficiency of carotenoid-rich extract as natural antioxidant compared to synthetic antioxidant (BHT) with its known side effects. The carotenoid-rich extract turned out to be pro-oxidant at a high level.

\section{REFERENCES}

Adjé F, Lozano YF, Lozano P, Adima A, Chemat F, Gaydou EM. 2010. Optimization of anthocyanin, flavonol and phenolic acid extractions from Delonix regia tree flowers using ultrasound-assisted water extraction. Ind. Crops Prod. 32, 439-444. https://doi.org/10.1016/j.indcrop.2010.06.011

Ammar I, BenAmira A, Khemakem I, Attia H, Ennouri M. 2017. Effect of Opuntia ficus-indica flowers maceration on quality and on heat stability of olive oil. J. Food Sci. Technol. 54, 1502-1510. https://doi.org/10.1007/s13197-017-2581-0

AOCS. 1998. Official Methods and Recommended Practices of the American Oil Chemists' Society, edited by Firestone D, 5 th edn, AOCS Press, Champaign, Illinois.

Bhatt DC, Mitaliya KD, Mehta SK, Patel NK. 2000. Flowers employed as gulkand in medicine. Adv. Plant Sci. 13, 539-542.

Chemat F, Rombaut N, Sicaire AG, Meullemiestre A, FabianoTixier AS, Abert-Vian M. 2018. Ultrasound assisted extraction of food and natural products. Mechanisms, techniques, combinations, protocols and applications. A Review. Ultrason. Sonochem. 34, 540-560. https://doi. org/10.1016/j.ultsonch.2016.06.035

Codex Alimentarius Commission 2015. Codex Standard for Named Standard for Edible Fats and Oils. Codex Stan 19-1981. p. 4.
Goula AM, Ververi M, Adamopoulou A, Kaderides K. 2017. Green ultrasound-assisted extraction of carotenoids from pomegranate wastes using vegetable oils. Ultrason. Sonochem. 34, 821-830. https://doi.org/10.1016/j.ultsonch. 2016.07.022

Gulluce M, Sahin F, Sokmen M, Ozer H, Daferera D, Sokmen A, Polissiou M, Adiguzel A, Ozkan H. 2007. Antimicrobial and antioxidant properties of the essential oils and methanol extract from Mentha longifolia L. ssp. longifolia. Food Chem. 103, 1449-1456. https://doi.org/10.1016/j. foodchem.2006.10.061

Hornero-Méndez D, Mínguez-Mosquera MI. 2000. Xanthophyll esterification accompanying carotenoid over accumulation in chromoplast of Capsicum annuum ripening fruits is a constitutive process and useful for ripeness index. J. Agric. Food Chem. 48, 1617-1622. https://doi.org/10.1021/jf9912046

Mezza GN, Borgarello AV, Grosso NR, Fernandez H, Pramparo MC, Gayol MF. 2018. Antioxidant activity of rosemary essential oil fractions obtained by molecular distillation and their effect on oxidative stability of sunflower oil. Food Chem. 242, 9-15. https://doi.org/10.1016/j. foodchem.2017.09.042

Nour V, Corbu AR, Rotaru P, Karageorgou I, Lalas S. 2018. Effect of carotenoids, extracted from dry tomato waste, on the stability and characteristics of various vegetable oils. Grasas Aceites 69, e238. https://doi.org/10.3989/gya.0994171

Oyaizu M. 1986. Studies on products of browning reaction: Antioxidative activities of products of browning reaction prepared from glucosamine. Jpn. J. Nutr. 44, 307-315. https://doi.org/10.5264/eiyogakuzashi.44.307

Polyakov NE, Leshina TV, Kovalova TA, Kispert LD. 2001. Carotenoids as scavengers of free radicals in a fenton reaction: Antioxidants or pro-oxidants? Free Radical Biol. Med. 31, 398-404. https://doi.org/10.1016/ S0891-5849(01)00598-6

Raso J, Mañas P, Pagán R, Sala FJ. 1999. Influence of different factors on the output power transferred into solvent by ultrasound. Ultrason. Sonochem. 5, 157-162.

Raza A, Li F, Xu X, Tang J. 2017. Optimization of ultrasonicassisted extraction of antioxidant polysaccharides from the stem of Trapa quadrispinosa using response surface methodology. Int. J. Biol. Macromol. 94, 335-344. https:// doi.org/10.1016/j.ijbiomac.2016.10.033

Rodriguez-Amaya DB. 2001. A guide to carotenoid analysis in foods. International Life Sciences Institute (ILSI) Press, Washington DC.

Roselló-Soto E Galanakis CM, Brnčić M, Orlien V, Trujillo FJ, Mawson R, Knoerzer K, Tiwari BK, Barba FJ. 2015. Clean recovery of antioxidant compounds from plant foods, byproducts and algae assisted by ultrasounds processing. Modeling approaches to optimize processing conditions. Trends Food Sci. Technol. 42, 134-149. https://doi. org/10.1016/j.tifs.2015.01.002

Sachindra NM, Mahendrakar NS. 2005. Process optimization for extraction of carotenoids from shrimp waste with vegetable oils. Bioresour. Technol. 96, 1195-1200. https://doi. org/10.1016/j.biortech.2004.09.018

Sachindra NM, Mahendrakar NS. 2010. Stability of carotenoids recovered from shrimp waste and their use as colorant in fish sausage. J. Food Sci. Technol. 47, 77-83. https://doi. org/10.1007/s13197-010-0019-Z

Saini RK, Keum YS. 2018. Carotenoid extraction methods: A review of recent developments. Food Chem. 240, 90-103. https://doi.org/10.1016/j.foodchem.2017.07.099

Shabir G, Anwar F, Sultana B, Khalid ZM, Afzal M, Khan QM, Ashrafuzzaman M. 2011. Antioxidant and antimicrobial attributes and phenolics of different solvent extracts from leaves, flowers and bark of Gold Mohar [Delonix regia (Bojer ex Hook.) Raf]. Molecules 16, 7302-7319. https://doi.org/10.3390/molecules16097302

Sricharoen P, Limchoowong N, Techawongstien S, Chanthai S. 2016. A novel extraction method for $\beta$-carotene and other carotenoids in fruit juices using air-assisted, low-density solvent-based liquid-liquid microextraction and solidified floating organic droplets. Food Chem. 203, 386-393. https://doi.org/10.1016/j.foodchem.2016.02.093 
Tiwari BK, Patras A, Brunton N, Cullen PJ, O’Donnell CP. 2010. Effect of ultrasound processing on anthocyanins and color of red grape juice. Ultrason. Sonochem. 17, 598-604. https://doi.org/10.1016/j.ultsonch.2009.10.009

Upadhyay R, Mishra HN. 2015. Multivariate analysis for kinetic modeling of oxidative stability and shelf life estimation of sunflower oil blended with sage (Salvia officinalis) extract under Rancimat conditions. Food Bioprocess Technol. 8, 801-810. https://doi.org/10.1007/s11947-014-1446-z

Upadhyay R, Nachiappan G, Mishra HN. 2015. Ultrasoundassisted extraction of flavonoids and phenolic compounds from Ocimum tenuiflorum leaves. Food Sci. Biotechnol. 24, 1951-1958. https://doi.org/10.1007/s10068-015-0257-y

Upadhyay R, Sehwag S, Mishra HN. 2017. Chemometric approach to develop frying stable sunflower oil blends stabilized with oleoresin rosemary and ascorbyl palmitate. Food Chem. 218, 496-504. https://doi.org/10.1016/j. foodchem.2016.09.105
Vargas AMM, Garcia CA, Reis EM, Lenzi E, Costa WF, Almeida VC. 2010. NaOH-activated carbon from flamboyant (Delonix regia) pods: Optimization of preparation conditions using central composite rotatable design. Chem. Eng. J. 162, 43-50. https://doi.org/10.1016/j.cej. 2010.04.052

Veigas JM, Divya P, Neelwarne B. 2012. Identification of previously unreported pigments among carotenoids and anthocyanins in floral petals of Delonix regia (Hook.) Raf. Food Res. Int. 47, 116-123. https://doi.org/10.1016/j. foodres.2012.02.008

Wang L, Weller CL. 2006. Recent advances in extraction of nutraceuticals from plants. Trends Food Sci. Technol. 17, 300-312. https://doi.org/10.1016/j.tifs.2005.12.004

Ye J, Feng L, Xiong J, Xiong Y. 2011. Ultrasound-assisted extraction of corn carotenoids in ethanol. Int. J. Food Sci. Technol. 46, 2131-2136. https://doi.org/10.1111/j.1365-2621. 2011.02727.x 